\title{
PERLINDUNGAN HUKUM TERHADAP PEMEGANG HAK MEREK DAGANG DI KOTA BATAM
}

\author{
Dwi Afni Maileni \\ Program Studi Ilmu Hukum, Fakultas Hukum, Universitas Riau Kepulauan, Indonesia \\ dwi.afni.maileni@gmail.com
}

\begin{abstract}
Abstrak
Kota Batam merupakan salah satu kota terbesar di Kepulauan Riau dengan letak yang sangat strategis yaitu berada di pelayaran internasional dan juga memiliki jarak yang cukup dekat dengan negara Malaysia dan Singapura. Letaknya yang strategis ini dapat menjadi peluang untuk dapat menjadi pintu dalam memasarkan produk Indonesia ke negara tetangga. Produk yang dihasilkan tidak lepas dari merek itu sendiri. Sebuah merek dapat menimbulkan persaingan usaha tidak sehat karena melalui merek produk barang atau jasa sejenis dapat dibedakan asal muasalnya, kualitasnya serta keterjaminan bahwa suatu produk tersebut Original. Melalui merek sebuah perusahaan telah membangun suatu karakter terhadap produk-produknya, yang diharapkan akan dapat membentuk reputasi bisnis yang meningkat atas penggunaan merek tersebut. Penelitian yang dilakukan oleh peneliti adalah penelitian hukum normative, dengan data primernya yaitu sumber data yang diperoleh langsung dilapangan yaitu melalui wawancara dengan staff Divisi Hukum dan HAM Direktorat Jendral Hak Kekayaan Intelektual Kota Batam. Semua data yang diperoleh kemudian dianalisis dengan menggunakan analisis kualitatif.Hasil penelitian ini menunjukan bahwa Perlindungan hukum bagi pemegang hak merek dagang Dikota Batam pada tahun 2016 sudah mendapatkan perlindungan hukum yang baik. Pemohon pendaftarn merek dagang pada Tahun 2016 di Kota Batam berjumlah 18 pendaftar dan sepanjang tahun 2016 tidak terdapat pelanggaran merek dikota batam, Jika dikota Batam ditemui merek-merek palsu hal tersebut dikarenakan kurangnya pemahaman masyarakat akan perlindungan hukum bagi pemegang hak merek dagang itu sendiri, dalam proses hukum untuk pelanggaran merek sendiri haruslah berdasarkan delik aduan, jika tidak adanya delik aduan dari pemegang hak merek itu sendiri dan masyarakat maka pelanggaran atas merek itu sendiri tidak dapat diproses secara hukum.Untuk mendapatkan perlindungan hukum bagi pemegang merek terdapat tuntutan pidana bagi pelanggarnya yang telah diatur pada pasal 100 ayat 1,2 dan 3 Undang undang No.20 tahun 2016 tentang Merek dan indikasi Geografis.

Kata Kunci: merek dagang, pemegang hak merek, undang-undang merek dan geografis.
\end{abstract}

\begin{abstract}
The city of Batam is one of the largest cities in the Riau Islands with a very strategic location that is located on international shipping and also has a fairly close distance to Malaysia and Singapore. This strategic location can be an opportunity to be a door in marketing Indonesian products to neighboring countries. The resulting product can not be separated from the brand itself. A trademark may create unfair business competition because through a product brand the same kind of goods or services can be distinguished from its origin, quality and assurance that a product is Original. Through the brand of a company has built a character to its products, which is expected to be able to form an increasing business reputation for the use of the brand. Research conducted by the researcher is normative legal research, with primary data that is data source obtained directly in the field that is through interview with staff of Division of Law and Human Right of Directorate General of Intellectual Property Rights of Batam City. All the data obtained were then analyzed using qualitative analysis. The results of this study indicate that the legal protection for the holder of trademark rights Batam City in 2016 already get a good legal protection. Applicant of trademark registrar in the year 2016 in Batam City amounted to 18 registrants and throughout 2016 there was no violation of the brand in the city Batam, If the city of Batam encountered fake brands it is due to lack of public understanding of the legal protection for the trademark holder's own rights, in the legal process for the breach of the brand itself must be based on the offense of complaint, in the absence of
\end{abstract}


a claim offense from the holder of the trademark itself and the public, the breach of the mark itself can not be processed by law. To obtain legal protection for the holder of the mark there are criminal charges for violators set forth in article 100, paragraphs 1,2 and 3 of Act 20 of 2016 on Brands and Geographical indications.

Keywords: trademarks, batam brand rights holders, brand laws and geographical indications.

\section{PENDAHULUAN}

Salah satu perkembangan yang kuat dan memperoleh perhatian seksama dalam sepuluh tahun ini dan kecendrungan yang masih akan berlangsung dimasa yang akan datang adalah semakin meluasnya arus globalisasi baik bidang sosial, ekonomi, budaya maupun bidang-bidang kehidupan lainnya. Perkembangan teknologi informasi dan transportasi telah menjadikan kegiatan disektor perdagangan meningkat secara pesat dan bahkan telah menempatkan dunia sebagai pasar tunggal bersama.

Era perdagangan global hanya dapat dipertahankan jika terdapat iklim persaingan usaha yang sehat. Disini merek memegang peranan yang sangat penting yang memerlukan sistem pengaturan yang lebih memadai. Berdasarkan pertimbangan tersebut dan sejalan dengan perjanjian-perjanjian internasional yang telah diratifikasi Indonesia serta pengalaman melaksanakan administrasi merek, diperlukan penyempurnaan Undang-undang Merek yaitu Undang-undang Nomor 19 tahun 1992 (lembaran Negara Tahun 1992 Nomor 81)sebagaimana diubah dengan Undang-undang Nomor 14 Tahun 1997 (lembaran Negara Tahun 1997 Nomor 31) dan selanjutnya diubah kembali dengan Undang-undang Nomor 16 Tahun 2016 tentang Merek dan Indikasi Geografis.

Merek sangat penting dalam dunia periklanan dan pemasaran karena publik sering mengaitkan suatu imej, kualitas atau reputasi barang dan jasa dengan merek tertentu. Sebuah merek dapat menjadi kekayaan yang sangat berharga secara komersial. Merek suatu perusahaan seringkali lebih bernilai dibandingkan dengan asset riil perusahaan tersebut.

Merek juga berguna untuk para konsumen. Mereka membeli produk tertentu (yang terlihat dari mereknya) karena menurut mereka, merek tersebut berkualitas tinggi atau aman untuk dikonsumsi dikarenakan reputasi dari merek tersebut. Jika sebuah perusahaan menggunakan merek perusahan lain, para konsumen mungkin merasa tertipu karena telah membeli produk dengan kualitas yang lebih rendah.

Asal usul merek sendiri berpangkal disekitar abad pertengahan di Eropa, pada saat perdagangan dengan dunia luar mulai berkembang. Fungsinya semula untuk menunjukkan 
asal produk yang bersangkutan. Baru setelah dikenal metode produksi massal dan dengan jaringan distribusi dan pasar yang lebih luas dan kian rumit, fungsi merek berkembang menjadi seperti yang dikenal sekarang ini .

Merek menjadi salah satu kata yang sangat populer yang sering digunakan dalam hal mempublikasikan produk baik itu lewat media massa seperti di surat kabar, majalah, dan tabloid maupun lewat media elektronik seperti di televisi, radio dan lain-lain. Seiring dengan semakin pesatnya persaingan dalam dunia perdagangan barang dan jasa ahkir-akhir ini maka tidak heran jika merek memiliki peranan yang sangat signifikan untuk dikenali sebagai tanda suatu produk tertentu di kalangan masyarakat dan juga memiliki kekuatan serta manfaat apabila dikelola dengan baik. Merek bukan lagi kata yang hanya dihubungkan dengan produk atau sekumpulan barang pada era perdagangan bebas sekarang ini tetapi juga proses dan strategi bisnis. Oleh karena itu, merek mempunyai nilai atau ekuitas. Dan ekuitas menjadi sangat penting karena nilai tersebut akan menjadi tolak ukur suatu produk yang ada dipasaran.

Disini Hak Merek merupakan bagian dari HKI. Merek dianggap sebagai "roh" dari suatu produk. Bagi pengusaha, merek merupakan aset yang sangat bernilai karena merupakan ikon kesuksesan sejalan usahanya yang dibangun dengan segala keuletan termasuk biaya promosi. Bagi produsen merek dapat digunakan sebagai jaminan mutu hasil produksinya. Merek Terdaftar, sering disimbolkan dengan tanda. Setelah meratifikasi WTO Agreement, Indonesia melakukan banyak revisi terhadap berbagai undang-undang di bidang Hak Kekayaan Intelektual yang ada.

Ditinjau dari aspek hukum masalah merek menjadi sangat penting, sehubungan dengan persoalan perlu adanya perlindungan hukum dan kepastian hukum bagi pemilik atau pemegang merek dan perlindungan hukum terhadap masyarakat sebagai konsumen atas suatu barang atau jasa yang memakai suatu merek agar tidak terkecoh oleh merek-merek lain, tidak dapat dipungkiri lagi bahwa masalah penggunaan merek terkenal oleh pihak yang tidak berhak, masih banyak terjadi di Indonesia dan kenyataan tersebut benar-benar disadari oleh pemerintah, tetapi dalam praktek banyak sekali kendala-kendala sebagaimana dikatakan oleh A Zen Umar Purba (mantan Dirjen HaKI) bahwa Law Enforcement yang lemah. Memang tidak dapat selamanya dijadikan alasan tetapi yang perlu diperhatikan adalah mengapa hal itu bisa terjadi. Hal itu tidak dapat dilepaskan dari sisi historis masyarakat Indonesia yang sejak dahulu adalah masyarakat agraris, sehingga terbiasa segala sesuatunya dikerjakan dan 
dianggap sebagai milik bersama, bahkan ada anggapan dari para pengusaha home industri bahwa merek adalah mempunyai fungsi sosial. Pada satu sisi keadaan tersebut berdampak positif tetapi pada sisi lain justru yang anggapan demikian itu menyebabakan masyarakat kita sering berpikir kurang ekonomis dan kurang inovatif.

Kota Batam merupakan salah satu kota terbesar di Kepulauan Riau dengan letak yang sangat strategis yaitu berada di pelayaran internasional dan juga memiliki jarak yang cukup dekat dengan negara Malaysia dan Singapura. Letaknya yang strategis ini dapat menjadi peluang untuk dapat menjadi pintu dalam memasarkan produk Indonesia ke negara tetangga. Produk yang dihasilkan tidak lepas dari merek itu sendiri. Sebuah merek dapat menimbulkan persaingan usaha tidak sehat karena melalui merek produk barang atau jasa sejenis dapat dibedakan asal muasalnya, kualitasnya serta keterjaminan bahwa suatu produk tersebut Original. Melalui merek sebuah perusahaan telah membangun suatu karakter terhadap produk-produknya, yang diharapkan akan dapat membentuk reputasi bisnis yang meningkat atas penggunaan merek tersebut.

Upaya pemilik merek untuk mencegah pemakaian mereknya oleh pihak lain merupakan hal yang sangat penting dan sepatutnya dilindungi oleh hukum. Berkaitan dengan perlindungan merek, perdagangan tidak akan berkembang jika merek tidak mendapat perlindungan hukum yang memadai di suatu Negara termasuk negara Indonesia dan khususnya kota Batam. Pembajakan, plagiat atau pelanggaran-pelanggaran merek tentunya tidak hanya merugikan para pengusahanya saja sebagai pemilik atau pemegang hak atas merek tersebut, tetapi juga bagi para konsumen. Berdasarkan uraian tersebut maka timbul gagasan peneliti untuk meneliti Bagaimana Perlindungan Hukum tentang Pemegang Hak Merk Dagang di kota Batam Ditinjau Berdasarkan Undang-Undang Nomor 20 Tahun 2016 Tentang Merek dan Indikasi Geografis?

\section{METODE PENELITIAN}

Penelitian yang dilakukan oleh peneliti adalah penelitian hukum normatif yakni meggunakan sumber data sekunder yang berupa peraturan perundang-undangan, teori hukum, dan pendapat para sarjana.Sumber data adalah suatu keterangan atau fakta dari objek yang diteliti. Dalam penelitian ini peneliti menggunakan dua jenis data yaitu: 
1. Data primer yaitu sumber data yang diperoleh langsung dilapangan yaitu melalui wawancara dengan staff Divisi Hukum dan HAM Direktorat Jendral Hak Kekayaan Intelektual Kota Batam.

2. Data sekunder adalah data yang diperoleh secara tidak langsung yang berupa dokumen-dokumen, fakta-fakta yang diperoleh dari dokumen resmi serta peraturan perundang-undangan. Data sekunder ini terdiri dari:

a. Bahan hukum primer yang terdiri dari beberapa peraturan perundangundangan yang berkaitan dengan hukum Merk yaitu Undang- Undang Nomor 20 Tahun 2016 tentang Merek dan Indikasi Geografis, Kitab Undang-undang Hukum Perdata.

b. Bahan hukum sekunder yaitu bahan hukum yang terdiri dari buku- buku dan tulisan-tulisan ilmiah hukum yang berkaitan dengan objek hukum.

c. Bahan hukum tersier yaitu bahan- bahan yang memberikan informasi tentang bahan-bahan hukum primer dan sekunder antara lain kamus-kamus, ensikplodia, majalah, surat kabar.

Metode yang digunakan dalam penelitian ini studi lapangan dan studi pustaka. Studi lapangan merupakan rancangan penelitian yang mencakup pengkajian satu unit penelitian secara intensif, misalnya permasalahan-permasalahan yang pernah terjadi di Direktorat Jenderal Hak Kekayaan Intelektual kota Batam, mengenai perlindungan hukum bagi pemegang hak merk. Pengambilan data dapat melalui kuesioner, wawancara, observasi maupun data dokumen.Studi pustaka merupakan metode yang digunakan untuk pengumpulan bahan hukum yang diperlukan dalam penelitian ini diperoleh dengan cara melakukan studi kepustakaan. Perolehan bahan hukum melalui penelitian kepustakaan disimpulkan dengan cara mencari mempelajari serta memahami buku-buku ilmiah.

Teknik pengumpulan data yang digunakan peneliti adalah sebagai berikut: Pengamatan (observasi) adalah teknik pengumpulan data dengan cara melakukan pengamatan yang dilakukan secara langsung terhadap objek penelitian kemudian dilakukan pencatatan dilapangan, dalam hal ini penulis melakukan pengamatan secara langsung di Direktorat Jenderal HAKI kota Batam.Wawancara (interview) yaitu pengumpulan data yang dilakukan dengan cara wawancara kepada narasumber. Tanya jawab ini dilakukan secara langsung kepada para petugas maupun pejabat tertentu yang berwenang di Direktorat Jenderal HAKI Kota Batam terhadap segala sesuatu yang berhubungan dengan pembahasan. Adapun 
narasumber yang bersangkutan adalah Bapak Rizki A. R, S.H, selaku analis penyuluhan hukum pendaftaran merk Dirjend HAKI kota Batam.

Analisis data digunakan untuk menyederhanakan data kedalam bentuk yang lebih mudah dipahami. Semua data yang diperoleh kemudian dianalisis dengan menggunakan analisis kualitatif. Dalam penelitian ini dibutuhkan data-data yang akan dijadikan alat untuk menganalisis data. Data tersebut dapat diperoleh dari studi lapangan dan studi pustaka yang menggunakan sumber data primer dan sumber data sekunder.Setelah analisis analisis data selesai, maka hasilnya akan disajikan secara deskriptif, yaitu dengan, menuturkan dan menggambarkan apa adanya sesuia dengan permasalahan yang diteliti. Dari hasil tersebut kemudian ditarik kesimpulan yang diangkat dalam penelitian ini.

\section{PEMBAHASAN}

\section{Pengertian Merek}

Suatu merek bagi produsen barang atau jasa sangat penting, karena berfungsi untuk membedakan antara barang atau jasa satu dengan yang lainnya serta berfungsi sebagai tanda untuk membedakan asal-usul, citra reputasi maupun bonafiditas diantara perusahaan yang satu dengan yang lainnya yang sejenis. Bagi konsumen dengan makin beragamnya barang dan jasa yang berada dipasaran melalui merek dapat diketahui kualitas dan asal-usul dari barang tersebut.

Dalam kamus bahasa Indonesia Merek diartikan sebagai tanda yang dikenalkan oleh pengusaha (pabrik, produsen, dsb) pada barang barang yang dihasilkan sebagai tanda pengenal atau cap (tanda) yang menjadi pengenal untuk menyatakan nama dan sebagainya. Secara yuridis pengertian merek tercantum dalam pasal 1 ayat (1) UU No. 20 tahun 2016 yang berbunyi :

"Merek adalah tanda yang dapat ditampilkan secara grafis, berupa gambar, logo, naa, kata, huruf, angka, susunan, warna dalam bentuk 2 (dua) dimensi dan/ atau 3 (tiga) dimensi, suara, hologram, atau kombinasi dari 2 (dua) atau lebih unsur tersebut untuk membedakan barang dan/atau jasa yang diproduksi oleh orang atau badan hukum dalam kegiatan perdagangan barang dan/atau jasa.".

Dari rumusan pasal 1 ayat (1) UU Merek tersebut ada beberapa unsur dalam pengertian merek yaitu:

1. tanda

2. memiliki daya pembeda 
3. digunakan untuk perdagangan barang atau jasa.

Dalam dunia perdagangan terdapat perbedaan tingkat derajat sentuhan kemashuran yang dimiliki oleh merek, tingkatan merek tersebut dimulai dari merek biasa atau "normal mark" kemudian merek terkenal atau "well-known mark"dan yang tertinggi ialah merek termashur atau "famous mark". Untuk lebih mengetahui tentang merk itu, maka peneliti menyajikan teori pengertian merek dari yakni :

1. Berdasarkan Undang-Undang No. 20 Tahun 2016 Bab 1 Pasal 1 Ayat 1 Merek adalahtanda yang dapat ditampilkan secara grafis, berupa gambar, logo, naa, kata, huruf, angka, susunan, warna dalam bentuk 2 (dua) dimensi dan/ atau 3 (tiga) dimensi, suara, hologram, atau kombinasi dari 2 (dua) atau lebih unsur tersebut untuk membedakan barang dan/atau jasa yang diproduksi oleh orang atau badan hukum dalam kegiatan perdagangan barang dan/atau jasa."

2. Menurut Philip Kotler menyatakan bahwa: "Merek adalah tanda yang berupa gambar, nama, kata, huruf-huruf, angka-angka, susunan warna, atau kombinasi dari unsurunsur tersebut yang memiliki daya pembeda dan digunakan dalam kegiatan perdagangan dan jasa.”

3. Adapun pengertian merk menurut Djaslim Saladin menyatakan bahwa: "Merk adalah suatu nama, istilah, tanda, lambang atau desain, atau gabungan semua yang diharapkan mengidentifikasikan barang atau jasa dari seorang penjual atau sekelompok penjual, dan diharapkan akan membedakan barang atau jasa dari produk pesaing."

4. Selanjutnya menurut DR. Buchori Alma "Merek adalah tanda atau simbol yang memberikan identitas suatu barang atau jasa tertentu yang dapat berupa kata-kata, gambar atau kombinasi keduanya."

Merek tidak hanya berfungsi sebagai tanda pengenal tetapi harus juga dapat berfungsi sebagai tanda pembeda yang jelas. Agar suatu lambang yang mungkin berbentuk lukisan atau gambar dan sebagainya bisa dibedakan dengan tanda atau lambang yang dipakai oleh orang lain, maka lambang tersebut harus mempunyai ciri khusus yang dilekatkan pada suatu benda atau barang yang merupakan media sehingga melahirkan suatu tanda tadi menjadi merek. Supaya produk atau jasa yang dibubuhi lambang tertentu bisa berkembang menjadi merek yang melambangkan simbol dan mitos maka barang yang bersangkutan harus dikenal secara umum baik pada suatu negara tertentu maupun dikenal secara intenasional. 
Tujuan dari penggunaan merek adalah untuk memperlancar kegiatan perdagangan barang atau jasa yang sangat diperlukan dalam pelaksanaan pembangunan, maka dari perlindungan merek pada dasarnya tidak hanya untuk kepentingan pemilik merek saja akan tetapi juga untuk kepentingan masyarakat luas sebagai konsumen.

Merek merupakan salah satu kunci pertimbangan dalam keputusan bisnis. Merek adalah modal intelektual yang memiliki nilai ekonomi yang dapat ditingkatkan nilainya dalam produk dan teknologi. Merek adalah asset bisnis dan usaha. Merek sangat erat dengan busines image, goodwil dan reputasi.

Merek dagang adalah merek yang digunakan pada barang yang diperdagangkan oleh seseorang atau beberapa orang secara bersama-sama atau badan hukum untuk membedakan dengan barang-barang sejenis lainnya. Merek jasa adalah merek yang digunakan pada jasa yang diperdagangkan oleh seseorang atau beberapa orang secara bersama-sama atau badan hukum untuk membedakan dengan jasa-jasa sejenis lainnya.

Kotler menambahkan bahwa suatu merek adalah suatu simbol yang komplek yang menjelaskan enam tingkatan pengertian, yaitu:

1. Atribut produk, merek memberikan ingatan pada atribut - atribut tertentu dari suatu produk, misalnya jika kita mendengar merek Nutrisari, tentunya kita teringat akan minuman rasa jeruk.

2. Manfaat, Atribut - atribut produk yang dapat diingat melalui merek harus dapat diterjemahkan dalam bentuk manfaat baik secara fungsional dan manfaat secara emosional, misalnya atribut kekuatan kemasan produk menterjemahkan manfaat secara fungsional dan atribut harga produk menterjemahkan manfaat secara emosional yang berhubungan dengan harga diri dan status.

3. Nilai, Merek mencerminkan nilai yang dimiliki oleh produsen sebuah produk, misalnya merek Sony mencerminkan produsen elektronik yang memiliki teknologi yang canggih dan modern.

4. Budaya, Merek mempresentasikan suatu budaya tertentu, misalnya Mercedes mempresentasikan budaya Jerman yang teratur, efisien, dan berkualitas tinggi.

5. Kepribadian,Merek dapat diproyeksikan pada suatu kepribadian tertentu, misalnya Isuzu Panther yang diasosikan dengan kepribadian binatang panther yang kuat (mesin kuat dan tahan lama). 


\section{Perlindungan Hukum Bagi Merk Di Indonesia}

Sebagaimana diketahui, bahwa perlindungan merek di Indonesia, semula diatur dalam Reglement Industriele Eigendom Kolonien 1912, yang kemudian diperbaharui dan diganti dengan Undang-undang Nomor 21 Tahun 1961 tentang Merek Perusahaan dan Merek Perniagaan (disebut pula Undang-Undang Merek 1961). Adapun pertimbangan lahirnya Undang-Undang Merek 1961 ini adalah untuk melindungi khalayak ramai dari tiruan barangbarang yang memakai suatu merek yang sudah dikenalnya sebagai merek barang-barang yang bermutu baik. Selain itu, Undang-Undang Merek 1961 juga bermaksud melindungi pemakai pertama dari suatu merek di Indonesia.

Selanjutnya, pengaturan hukum merek yang terdapat dalam Undang-Undang Merek 1961, diperbaharui dan diganti lagi dengan Undang-undang Nomor 19 Tahun 1992 tentang Merek (selanjutnya disebut Undang-undang Merek 1992), yang mulai berlaku sejak tanggal 1 April 1993. Dengan berlakunya Undang-undang Merek 1992, Undang-undang Merek 1961 dinyatakan tidak berlaku lagi. Pada prinsipnya Undang-Undang Merek 1991 telah melakukan penyempurnaan dan perubahan terhadap hal-hal yang berkaitan dengan merek, guna disesuaikan dengan Paris convention.

Undang-undang Nomor 19 Tahun 1992, disempurnakan lagi dengan Undang-undang Nomor 14 Tahun 1997. Penyempurnaan undang-undang terus dilakukan,dengan disempurnankannya lagi Undang-undang No. 15 Tahun 2001 tentang Merek (Lembaran Negara Tahun 2001 Nomor 110, Tambahan Lembaran Negara Tahun 4131), yang mulai berlaku sejak tanggal 1 Agustus 2001. Dan hingga tahun 2016 diperbaharui lagi dengan lahirnya undang-undang Nommor 20 Tahun 2016 Tentang Merek dan Indikasi Geografis.

\section{Daya Pembeda Pada Merk}

Daya pembeda memiliki kemampuan untuk digunakan sebagai tanda yang dapat membedakan hasil perusahaan yang satu dengan perusahaan yang lain. Tanda yang secara inheren memiliki daya pembeda (Inherently distinctiveness) dan dapat segera memperoleh perlindungan yaitu tanda yang dibentuk dari kata temuan (invented words) yang bagus sekali didaftarkan sebagai merek mencakup tanda yang bersifat:

1. Fanciful, Merek yang dibentuk dari kata khayalan (fanciful), bahkan kata-kata yang tidak ada dalam kamus paling baik untuk dijadikan merek karena tidak saja baru, 
tetapi juga secara substansi jelas berbeda dengan kata yang digunakan pada umumnya. Contohnya, Blackberry untuk merek telepon seluler (handphone), Google untuk mesin pencarian di internet, Dagadu Yogyakarta.

2. Arbitrary. Merek yang berubah-ubah (arbitrary) menampilkan merek yang sama bekali tidak terkait dengan produk, contohnya, Apple untuk komputer, Jaguar untuk mobil.

3. Suggestive. Merek yang bermaksud memberikan kesan (suggestive) dikaitkan dengan imajinasi konsumen untuk menerjemahkan informasi yang disampaikan melalui merek dan kebutuhan pesaing untuk menggunkan kata yang sama, contohnya, Facebook untuk jejaring pertemanan di internet

Tanda dianggap tidak memiliki daya pembeda apabila tanda tersebut terlalu sederhana seperti satu tanda garis atau satu tanda titik, ataupun terlalu rumit sehingga tidak jelas. Salah satu contoh Merek seperti ini adalah tanda tengkorak di atas dua tulang yang bersilang, yang secara umum telah diketahui sebagai tanda bahaya. Tanda seperti itu adalah tanda yang bersifat umum dan telah menjadi milik umum. Oleh karena itu, tanda itu tidak dapat digunakan sebagai Merek.

Merek tersebut berkaitan atau hanya menyebutkan barang atau jasa yang dimohonkan pendaftarannya, contohnya Merek Kopi atau gambar kopi untuk jenis barang kopi atau untuk produk kopi. Merek yang secara umum telah diketahui sebagai tanda yang bersifat umum dan telah menjadi milik umum (public domain) biasanya disebut generic, sehingga sama sekali tidak dapat memiliki daya pembeda (incapable of becoming distinctive), tidak dapat dilindungi meskipun telah digunakan dalam upayanya membangun secondary meaning. Sementara dalam contoh merek kopi yang merupakan deskripsi dari produknya yaitu kopi, hal ini disebut descriptive. Merek yang menggambarkan produknya (descriptive) sebenarnya masih dapat menjadi merek dengan membangun secondary meaning (makna lain) melalui penggunaan. Dengan demikian, secara teoritis, lebih bersifat deskriptif suatu terminologi yang digunakan sebagai merek, maka harus lebih tinggi upayanya untuk membangun secondary meaning. Secondary meaning dilakukan oleh sebuah merek yang bersifat deskriftif atau merek yang memiliki daya pembeda yang lemah, namun dapat didaftarkan setelah membuktikan melalui penggunaan di pasar yang artinya membangun persepsi konsumen. 


\section{Jenis-Jenis Merek}

Undang- undang merek tahun 2016 ada mengatur tentang jenis-jenis merek, yaitu sebagaimana tercantum didaam pasl 1 butir 2,3 dan 4, yaitu merek dagang, merek jas dan merek kolektif. Pengertian dari beberapa jenis merek tersebut adalah sebagai berikut:

a. Merek dagang adalahmerek yang digunakan pada barang yang diperdagangkan oleh seseorang atau beberapa orang secara bersama-sama atau badan hukum untuk membedakan barang barang sejenis lainnya.

b. Merek jasa adalah merek yang digunakan pada jasa yang diperdangkan oleh seseorang atau beberapa orang secara bersama sama atau oleh badan hukum untuk membedakan dengan jasa jasa sejenis lainnya.

c. Merek kolektif adlaah merek yang digunakan pada barang dan atau jasa dengan karakteristik yang sama, yang diperdagangkan oleh seseorang atau beberapa orang atau badan hukum secara bersama sama untuk membedakan dengan barang dan atau jasa sejenis lainnya.

Dalam perkembangannya ada beberapa jenis merek lainnya juga yang perlu untuk diketahui, yaitu sebagai berikut:

1. Merek perusahaan, Manufacturer brand atau merek perusahaan adalah merek yang dimiliki oleh suatu perusahaan yang memproduksi produk atau jasa. Contohnya seperti soffel, capilanos, ultraflu, so klin, philips, tessa, benq, faster, nintendo wii, vit, vitacharm, vitacimin, dan lain-lain.

2. Merek pribadi, Merek pribadi adalah merek yang dimiliki oleh distributor atau pedagang dari produk atau jasa seperti zyrex ubud yang menjual laptop cloud everex, hipermarket giant yang menjual kapas merek giant, carrefour yang menjual produk elektronik dengan merek bluesky, supermarket hero yang menjual gula dengan merek hero, dan lain sebagainya.

Ada juga produk generik yang merupakan produk barang atau jasa yang dipasarkan tanpa menggunakan merek atau identitas yang membedakan dengan produk lain baik dari produsen maupun pedagang. Contoh seperti sayur-mayur, minyak goreng curah, abu gosok, buah-buahan, gula pasir curah, bunga, tanaman, dan lain sebagainya. Selanjutnya R.M. Suryodiningrat (1981: 15) mengklasifikasikan merek dalam tiga jenis yaitu:

1. Merek kata yang terdiri dari kata-kata saja, misalnya Good Year, Dunlop, sebagai merek untuk ban mobil dan ban sepeda. 
2. Merek lukisan adalah merek yang terdiri dari lukisan saja yang tidak pernah, setidak2nya jarang sekali digunakan.

3. Merek kombinasi kata dan lukisan, banyak sekali dipergunakan, misalnya the wangi merek "pendawa" yang terdiri dari lukisan wayang kulit pendawa dengan perkataan dibawahnya "pendawa Lima".

Lebih lanjut Prof. R. Soekardono, S.H, (dalam Firmansyah, 2001: 29) mengemukakan pendapatnya bahwa, tentang bentuk atau wujud dari merek itu undang-undang tidak memerintahkan apa-apa, melainkan harus berdaya pembeda, yang diwujudkan dengan:
a. Cara yang oleh siapapun mudah dapat dilihat (bel mark).
b. Merek dengan perkataan (word mark).
c. Kombinasi dari mere katas penglihatan dan merek perkataan.

\section{Strategi Merek}

Produsen, distributor atau pedagang pengecer dapat melakukan strategi merek sebagai berikut di bawah ini :

\section{Individual Branding / Merek Individu}

Individual branding adalah memberi merek berbeda pada produk baru seperti pada deterjen surf dan rinso dari unilever untuk membidik segmen pasar yang berbeda seperti halnya pada wings yang memproduksi deterjen merek so klin dan daia untuk segmen pasar yang beda.

\section{Family Branding / Merek Keluarga}

Family branding adalah memberi merek yang sama pada beberapa produk dengan alasan mendompleng merek yang sudah ada dan dikenal mesyarakat. Contoh famili branding yakni seperti merek gery yang merupakan grup dari garudafood yang mengeluarkan banyak produk berbeda dengan merek utama gery seperti gery saluut, gery soes, gery toya toya, dan lain sebagainya. Contoh lain misalnya yaitu seperti motor suzuki yang mengeluarkan varian motor suzuki smash, suzuki sky wave, suzuki spin, suzuki thunder, suzuki arashi, suzuki shogun ,suzuki satria, dan lain-lain.

Perlindungan hukum bagi rakyat adalah sebuah tindakan Pemerintah yang bersifat preventif dan represif. Perlindungan hukum yang preventif bertujuan untuk mencegah terjadinya sengketa. Perlindungan hukum represif bertujuan untuk menyelesaikan terjadinya sengketa, termasuk penanganannya di lembaga peradilan (Hadjon, 1987: 2). 
Perlindungan hukum Hak Kekayaan Intelektual merupakan suatu sistem hukum yang terdiri dari unsur-unsur sistem berikut ini:

1. Subjek perlindungan, subjek yang dimaksud adalah pihak pemilik atau pemegang hak, aparat penegak hukum, pejabat pendaftaran, dan pelanggar hukum.

2. Objek perlindungan, objek yang dimaksud adalah semua jenis hak kekayaan intelektual yang diatur oleh undang-undang, seperti hak cipta, merek, paten, desain industry, rahasia dagang, tataletak sirkuit terpadu, perlindungan varietas tanaman.

3. Pendaftaran perlindungan, Hak kekayaan intelektual yang dilindungi hanyalah yang sudah terdaftar dan dibuktikan dengan sertifikat pendaftaran, kecuali apabila undang-undang mengatur lain, seperti hak cipta boleh tidak didaftarkan menurut undang-undang nomor 12 tahun 1997 (konsolidasi).

4. Jangka waktu perlindungan. Jangka waktu yang dimaksud adalah lamanya Hak Kekayaan Intelektual itu dilindungi oleh undang-undang: Hak Cipta selama hidup ditambah 50 (lima puluh) tahun sesudah meninggal, Merek 10 (sepuluh) tahun, Paten 20 (duapuluh) tahun, desain Industri 10 (sepuluh) tahun, Rahasia Dagang tanpa batas, sirkuit terpadu 10 (sepuluh) tahun, Varitas Baru Tanaman 20-25 (dua puluh sampai dengan dua puluh lima) tahun.

5. Tindakan hukum perlindungan. Apabila terbukti telah terjadi pelanggaran Hak Kekayaan Intelektual, maka pelanggaran harus dihukum, baik secara pidana maupun secara perdata.

Sebuah merek terdaftar dilindungi (berarti orang lain tidak dapat memakainya) selama jangka waktu sepuluh tahun dari tanggal penerimaan (pasal 35 ayat (1)). Jangka waktu ini dapat diperpanjang untuk masa yang tidak ditentukan selama 10 tahun (pasal 35 ayat (2)) dengan pembayaran biaya. Namun pemilik harus mengajukan perpanjangan 12 bulan sebelum merk tersebut berakhir (pasal 35 ayat (3)). Merek akan diperpanjang masa berlakunya hanya jika pemilik masih memakai merek tersebut dalam perdagangan barang dan/ atau jasa (pasal 36 huruf (a) dan (b)).

Seorang pemilik merek atau penerima lisensi merek dapat menuntut seorang yang tanpa izin, telah menggunakan merek yang memiliki persamaan pada pokoknya dengan 
merek orang lain yang bergerak dalam bidang perdagangan atau jasa yang sama (pasal 83 ayat (1)).

Berbicara masalah merek erat kaitannya dengan persaingan tidak jujur (unfair competition). Bila pengusaha dalam bidang perusahaan yang sejenis bersama-sama berusaha dalam daerah yang sama pula maka masing-masing dari mereka berusaha sekeras-kerasnya melebihi yang lainnya untuk mendapatkan tempat dihati masyarakat konsumen secara kompetitif, jadi tidak hanya merek yang dipertaruhkan, lebih dari itu yang dipertaruhkan adalah kualitas barang. Masalah mengenai merek diatur pula dalam Peraturan Pemerintah bidang merek, yaitu:

1. Peraturan Pemerintah Republik Indonesia Nomor 32 Tahun 1995 tentang Komisi Banding Merek ditetapkan Tanggal 29 Agustus 1995.

2. Peraturan Pemerintah Republik Indonesia Nomor 23 Tahun 1993 tentang Tata Cara Permintaan Pendaftaran Merek ditetapkan Tanggal 31 Maret 1993.

3. Peraturan Pemerintah Republik Indonesia Nomor 24 Tahun 1993 tentang Kelas Barang atau Jasa Bagi Pendaftaran Merek ditetapkan Tanggal 31 Maret 1993.

4. PP No.38 Tahun 2009 tentang Jenis dan Tarif atas Penerimaan Negara Bukan Pajak yang Berlaku pada Kementerian Hukum dan Hak Asasi Manusia.

Ada dua macam pemeriksaan kasus pelanggaran. Jika salah satu cara terpenuhi, penggugat akan menang. Penggugat harus membuktikan bahwa merek tergugat:

1. Memiliki persamaan pada pokoknya terhadap merek yang dimiliki penggugat; atau

2. Persamaan yang menyesatkan konsumen pada saat membeli produk atau jasa tergugat.

Bagaimana caranya memutuskan bahwa suatu merek dagang memiliki persamaan pada pokoknya dengan merek yang lain? Menurut bapak Rizki selaku divisi Hukum dan HAM Caranya adalah dengan membandingkan kedua merek dagang melihat persamaan dan perbedaan-perbedaanya, memperhatikan ciri-ciri penting dan kesan kemiripan atau perbedaan yang timbul. Jika merek-merek tersebut sama atau hampir sama, pelanggaran merek akan terjadi. Selanjutnya menurut beliau merek tergugat akan melanggar merek penggugat jika cenderung menipu konsumen (begitu sama/ mirip sehingga menyesatkan/ menyebabkan 
kebingungan bagi konsumen) sampai pada batas dimana mereka kemungkinan keliru membeli produk tergugat, padahal mereka sebenarnya bermaksud membeli produk penggugat. Yang perlu diingat disini adalah tujuan utama dari peraturan merek adalah melindungi bisnis dan mencegah orang-orang "membonceng" reputasi seseorang atau perusahaan. Jika merek dagang tergugat tidak memiliki persamaan pada pokoknya, tetapi memiliki cukup persamaan yang dapat membingungkan konsumen, selanjutnya persamaan tersebut akan mengurangi keuntungan penggugat karena konsumen berpikir bahwa mereka sedang membeli produk penggugat. Kenyataannya, mereka membeli produk orang lain.

Jika penggugat tidak mempunyai reputasi didaerah/ negara tempat tindakan passing off terjadi, penggugat tidak akan berhasil dalam kasus passing off . sebagai contoh, sebuah produk yang sudah lama dikenal seperti Aqua mempunyai reputasi bagus di Indonesia. Sebaliknya, sebuah produk baru mungkin belum memiliki reputrasi sehingga produk tersebut tidak dapat dilindungi oleh hukum passing off. Namun, aqua kemungkinan memiliki sedikit peluang untuk berhassil menuntut berdasarkan passing off di Australia karena produk tersebut jarang ditemui dinegara tersebut dan akibatnya tidak mempunyai reputasi di Australia.

Jadi passing off mencegah orang-orang melakukan dua hal yaitu pertama, menampilkan/ menyebabkan anggapanbahwa barang/ jasanya adalah barang/jas orang lain. Dan kedua, menimbulkan anggapan bahwa barang atau jasanya ada hubungan dengan barang/jasa pengugat.

Pasal 83 ayat (3) Undang undang Nomor 20 Tahun 2016 Tentang merek dan indikasi Geografis telah menentukan untuk persidangan kasus maka akan diselesaikan di Pengadilan Niaga. Sedangkan pada Pasal 88 ayat (7) menentukan Putusan pengadilan Niaga dapat diajukan kasasi ke Mahkamah Agung.

Penggugat harus menunjukkan bahwa reputasi yang menyesatkan dari tergugat telah menyebabkan kerugian nyata dan kerugian tersebut akan terus berlanjut jika aktivitas tergugat diteruskan. Penggugat dapat mengalami kerugian dalam tiga bentuk:

1. Penggugat dapat menunjukkan bahwa bisnisnya sudah menderita kerugian atau secara potencial menderita kerugian baik dalam itikad baik maupun reputasi bisnisnya. Penurunan itikad baik dapat disebabkan oleh diversi perdagangan tergugat sebagai akibat dari anggapan keliru tergugat yang menciptakan kesan 
palsu seolah-olah barang-barang atau jasa-jasa dari penggugat maupun tergugat adalah sama atau mempunyai karakter yang sama. Penggugat juga dapat menderita kerugian melalui "pencemara" reputasinya dimana anggapan yang keliru atas produk tergugat mengurangi kesan eksklusif atau reputasi dari produk penggugat.

2. Penggugat dapat menunjukkan bahwa tergugat merusak potensi penggugat untuk mempergunakan itikad baiknya dimasa yang akan datang.

3. Penggugat telah kehilangan kesempatan untuk mengembangkan usahanya dibidang lain.

Tuntutan pidana dalam tiap delik yang ditetapkan UU merk dan indikasi geografis adalah merupakan hak negara.pihak yang tidak berhak yang mencoba atau melakukan gangguan terhadap hak tersebut akan diancam dengan hukuman pidana. Adapun ancaman pidana yang termuat dalam pasal 100UU merek dan indikasi Geografis yaitu "barang siapa dengan sengaja dan tanpa hak menggunakan merek yang sama pada keseluruhannya dengan merek yang telah terdaftar milik pihak lain untuk barang dan/ atau sejenis yang diproduksi dan/atau diperdagangkan, dipidana dengan pidana penjara paling lama 5 tahun dan/ atau denda paling banyakRp. 2.000.000.000,-."

Merek memegang peranan penting dalam dunia perdagangan dan dalam melindungi reputasi yang dibangun oleh banyak perusahaan. Dimasa yang akan dating, undang-undang merek akan bertambah penting bagi Indonesia seiring dengan semakin meningkatnya perdagangan international diera Globalisasi.

Untuk mendapatkan perlindungan hukum bagi pemegang merek terdapat tuntutan pidana bagi pelanggarnya yang telah diatur pada pasal 100 ayat 1,2 dan 3 Undang undang No.20 tahun 2016 tentang Merek dan indikasi Geografis, yang berbunyi:

1. "Setiap orang yang dengan tanpa hak menggunakan Merek yang sama pada keseluruhannya dengan merek terdaftar milik pihak lain untuk barang dan/atau diperdagangkan, dipidana dengan pidana penjara paling lama 5 (lima) tahun dan/ atau pidana denda paling banyak Rp. 2.000.000.000,00(dua milyar rupiah)

2. Setiap orang yang dengan tanpa hak menggunakan merek yang mempunyai persamaan pada pokoknya dengan merek terdaftar milik pihak lain untuk barang dan/ atau jasa sejenis yang diproduksi dan/atau diperdagangkan dipidana dengan 
pidana penjara paling lama 4 (empat) tahun dan/atau denda paling banyak Rp. 2.000.000.000,00(dua milyar rupiah)

3. Setiap orang yang melanggar ketentuan sebagaimana dimaksud pad ayat (1) dan ayat (2), yang jenis barangnya mengakibatkan gangguan kesehatan, gangguan lingkungan hidup, dan/atau kematian, manusia, dipidana dengan pidana penjara paling lama 10 (sepuluh) tahun dan/atau denda paling banyak Rp. 5.000.000.000,00(lima milyar rupiah)."

Dengan perlindungan hukum yang terdapat pada pasal 100 ayat 1,2,dan 3 UU Merek dan indikasi Geografis tersebut maka hal tersebut juga berlaku di Kota Batam dengan tidak ada pengecualian. Di Batam sendiri walaupun ada beberapa kasus terkait Pelanggaran Merek, seperti kasus Nike, kasus casing Handphone namun sipemegang hak merek tetap mendapatkan perlindungannya, sesuai yang diatur pada UU Merek dan Indikasi Geografis. Direktur Penyidikan dan Penyelesaian Sengketa Ditjen Kekayan Intelektual (DJKI), Kementrian Hukum dan HAM, Salmon Pardede mengungkapkan, sepanjang tahun 2016 pihaknya telah menangani 33 kasus yang didominasi oleh kasus sengketa merek. Perlindungan hukum bagi pemegang hak merek dagang Dikota Batam sudah mendapatkan perlindungan hukum sesuai dengan apa yang diatur pada UU merek dan Indikasi Geografis. Dari hasil wawancara dengan bapak Rizki selaku divisi hukum dan Ham, Untuk Tahun 2016 perlindungan hukum sudah diberikan bagi pemegang merek di kota Batam, dalam konsep hukum dibutuhkan suatu upaya hukum preventif dan represif untuk melindungi pemegang merek itu sendiri agar tujuan perlindungan hukum itu sendiri terlaksana dengan baik. Selanjutnya menurut beliau Pemohon pendaftarn merek dagang pada Tahun 2016 di Kota Batam berjumlah 18 pendaftar, dan tidak terdapat pelanggaran merek. Jika dikota Batam ditemui merek-merek palsu hal tersebut dikarenakan kurangnya pemahaman masyarakat akan perlindungan hukum bagi pemegang hak merek dagang itu sendiri, dalam proses hukum untuk pelanggaran merek sendiri haruslah berdasarkan delik aduan, jika tidak adanya delik aduan dari pemegang hak merek itu sendiri dan masyarakat maka pelanggaran atas merek itu sendiri tidak dapat diproses secara hukum. Menurut Bapak Rizki selaku divisi hukum dan HAM, dikota Batam dapat diketahui Faktor- faktor yang mempengaruahi atas beredarnya merek-merek palsu tersebut adalah:

1. Pangsa pasar. Umumnya merek yang banyak diminati masyarakat yang dibajak. 
2. Kurang tegasnya peraturan tentang hak merek

3. Lemahnya pengawasan dari pelaksanakan peratutran tersebut

4. Animo masyarakat besar terhadap komoditas bermerk namun harga murah, kurang mempertimbangkan kualitas,

5. Daya beli masyarakat relatif masih rendah.

6. Tingkat kesadaran masyarakat tentang pelanggaran hak merek.

Perilaku masyarakat yang melakukan pelanggaran terhadap merek, menunjukkan bahwa masih rendahnya pemahaman terhadap norma-norma hukum yang berlaku khususnya yang tercantum dalam Undang-undang Merek dan Indikasi Geografis atau yang lebih kita kenal dengan kesadaran hukum. Kondisi perekonomian juga menjadi penyebab mengapa masyarakat cenderung lebih suka untuk membeli produk palsu, karena mereka lebih mementingkan harga yang ditawarkan dari produk palsu tersebut sekalipun kualitasnya jauh berbeda dari produk aslinya. Kesadaran hukum merupakan kesadaran atau nilai-nilai yang terdapat di dalam diri manusia tentang hukum yang ada atau tentang hukum yang di harapkan ada. Sebenarnya yang ditekankan adalah nilai-nilai tentang fungsi hukum dan bukan suatu penilaian hukum kejadian-kejadian yang konkrit dalam masyarakat yang bersangkutan. Mempermasalahkan kesadaran hukum yang dianggap sebagai mediator antara hukum dengan pola-pola perilaku manusia. Di dalam masyarakat (baik secara individual maupun kolektif) sebenarnya kesadaran hukum tersebut banyak sekali menyangkut aspek-aspek kognitif dan perasaan yang seringkali dianggap sebagai faktor-faktor yang mempengaruhi hubungan antara hukum dengan pola-pola perilaku manusia dalam masyarakat.

Selain itu faktor-faktor yang menghambat pelaksanaan UU Merek dan indikasi Geografis yakni Kurangnya pengetahuan/wawasan/informasi dari pihak pedagang, lemahnya kesadaran hukum dari para pihak baik pedagang ataupun konsumen, serta kurangnya pengawasan dari pihak terkait baik dari Disperindag ataupun dari pemilik merek menjadi kendala dalam proses pelaksanaan perlindungan hukum terkait perdagangan barang palsu. Belum maksimalnya upaya yang dilakukan untuk dapat menekan pelanggaran merek menyebabkan hingga saat ini peredaran barang-barang hasil pelanggaran masih terjadi. Pedagang sendiri selama ini terus memperdagangkan barang-barang palsu dengan menggunakan merek-merek terkenal seperti Nike, Adidas, Bilabong, Ripcurl, channel dan masih banyak lagi. Dari hasil penelitian itu diharapkan kedepan ada proses-proses untuk 
mengoptimalkan upaya-upaya perlindungan hukum dengan cara meningkatkan kesadaran hukum terhadap merek kepada pedagang dan konsumen untuk memperdagangkan dan membeli barang-barang palsu.

\section{KESIMPULAN}

Hasil penelitian ini menunjukan bahwa Perlindungan hukum bagi pemegang hak merek dagang Dikota Batam pada tahun 2016 sudah mendapatkan perlindungan hukum yang baik. Pemohon pendaftaran merek dagang pada Tahun 2016 di Kota Batam berjumlah 18 pendaftar dan sepanjang tahun 2016 tidak terdapat pelanggaran merek dikota batam, Jika dikota Batam ditemui merek-merek palsu hal tersebut dikarenakan kurangnya pemahaman masyarakat akan perlindungan hukum bagi pemegang hak merek dagang itu sendiri, dalam proses hukum untuk pelanggaran merek sendiri haruslah berdasarkan delik aduan, jika tidak adanya delik aduan dari pemegang hak merek itu sendiri dan masyarakat maka pelanggaran atas merek itu sendiri tidak dapat diproses secara hukum.

Untuk mendapatkan perlindungan hukum bagi pemegang merek terdapat tuntutan pidana bagi pelanggarnya yang telah diatur pada pasal 100 ayat 1,2 dan 3 Undang undang No.20 tahun 2016 tentang Merek dan indikasi Geografis.

Perlindungan hukum terhadap pemegang hak merek dagang dikota batam dibutukan upaya preventif dan represif agar dapat terlaksana dengan baik. Mengenai upaya preventif agar pengaturan tentang pelanggaran merek dagang tersebut lebih dipertegas dengan ancaman hukuman yang lebih berat dan disertai dengan diperbolehkannya aparat penegak hukum memproses secara hukum tanpa adanya dlik aduan dari masyarakat maupun pemegang hak merek, sosialisasi terhadap pengaturan pelanggaran merek juga dibutuhkan, pengawasan yang ketat dari berbagai pihak juga diperlukan untuk menghindari terjadinya pelanggaran merek, baik dari pihak dinas Kanwil Depkumham, Disperindag, maupun yang lainnya. selain itu kesadaran masyarakat harusnya lebih memahami bahwa mengkonsumsi barang yang tidak terindikasi pelanggaran merek akan lebih meminimalisir tindakan pelanggaran merek dagang itu sendiri.

Upaya represif diperlukan agar menindaklanjuti dari pelanggaran-pelanggaran terhadap merek dagang itu sendiri, dengan melaksanakan aturan dari uu merek dan indikasi geografis maka salah satu upaya represif itu akan terlaksana dengan baik sehingga perlindungan hukum terhadap pemegang merek itupun didapati. 


\section{DAFTAR PUSTAKA}

Asian Law Group Pty Ltd. (2013). Hak Kekayaan Intelektual suatu Pengantar. Bandung: PT Alumni.

Syamsudin, Didi Irwandi. (2000). Pemalsuan Merek Terkenal dan Dilema Penegakan Hukum. Majalah Eksekutif No. 250, Juli.

Djubaedillah. R. (2003). Sejarah, Teori dan Praktek Hak Milik Intelektual di Indonesia. Bandung: Citra Aditya Bakti.

Firmansyah, Hery. (2001). Perlindungan Hukum Terhadap Merek. Jakarta: Pustaka Yustisia.

Getas, Gede. LGst. (1994). Peranan Merek Dalam Dana Usaha. Denpasar: UPADA SASTRA.

Hadjon, Phillipus M. (1987). Perlindungan Hukum Bagi Rakyat Indonesia. Surabaya: PT. Bina Ilmu.

Maulana, Insan Budi. (2000). Merek Terkenal Menurut TRIPs Agreement, Temu Wicara Merek Terkenal, Direktorat Jenderal HaKI Departemen Hukum dan Perundangundangan. Jakarta, Maret.

(1997). Perlindungan Merek Terkenal di Indonesia dari Masa ke Masa. Bandung: Citra Aditya Bakti.

Wanita, Rizawanto. (2002). Undang Undang Merek Baru 2001. Bandung: Citra Aditya Bakti.

Saidin OK. (2007). Aspek Hukum hakkekayaan intelektual (intelellectual Property Rights). Jakarta: Raja Grafindo Persada.

Sjahputra, Imam, Herjandono, Heri Parjio. (1997). Hukum Merek Baru Indonesia Tanya Jawab Teori dan Praktek. Jakarta: Harvarindo.

Suryodiningrat, RM. (1981). Aneka Hak Milik Perindustrian. Bandung: Tarsito.

Undang- undang Nomor 20 Tahun 2016 Tentang Merek dan Indikasi Geografis

Undang- Undang Nomor 15 Tahun 2001 Tentang Merk 